\title{
ASESMEN DINAMIS : IMPLEMENTASI TEKNIK ASESMEN BERBASIS PERKEMBANGAN MOTORIK HALUS DI KELOMPOK BERMAIN AISYIYAH MUTIARA UMMI KALASAN, YOGYAKARTA
}

\author{
Firdha Hayati ${ }^{1}$ \& Asiah $^{2}$ \& Maulida ${ }^{3}$ \\ UIN Sunan Kalijaga Yogyakarta \\ Email: Firdhahayati0711@gmail.com
}

\begin{abstract}
This research is motivated by a child who experiences the development of fine motor skills that are different from other children, so the teacher starts implement a dynamic assessment strategy. The purpose of this study is to describe how the teacher implements a dynamic assessment strategy based on fine motor development in children in KB Mutiara Ummi Kalasan. The research method used in this study uses interview techniques and documentation studies. Then the data were analyzed using Miles \& Huberman analysis. The results show that the form of research used by the teacher concerned for children with the initials $A A$ is the form of an observation checklist and portfolio worksheets. Children who have the initials $A A$ have experienced fine motor development gradually, and the level of development of children is in the stage of developing (MB).
\end{abstract}

Keywords: dynamic assessment, development, fine motor skills

\begin{abstract}
Abstrak
Penelitian ini dilatarbelakangi oleh seorang anak yang mengalami perkembangan kemampuan motorik halus yang berbeda dengan anak lainnya, sehingga guru mulai mengimplementasikan strategi asesmen dinamis. Tujuan penelitian ini ialah untuk mendeskripsikan bagaimana guru mengimplementasikan strategi asesmen dinamis berbasis perkembangan motorik halus pada anak di KB Mutiara Ummi Kalasan. Metode penelitian yang digunakan pada penelitian ini menggunakan teknik wawancara dan studi dokumentasi. Kemudian data dianalisis menggunakan analisis Miles \& Huberman. Hasil menunjukkan bahwa bentuk penelitian yang digunakan oleh guru yang bersangkutan untuk
\end{abstract}




\section{JURNAL EDUKASI ANAK USIA DINI \\ PENDIDIKAN ISLAM ANAK USIA DINI \\ UNIVERSITAS ISLAM NEGERI ANTASARI BANJARMASIN}

anak yang berinisial $A A$ ialah bentuk penilaian observasi checklist dan lembar kerja portofolio. Anak yang berinisial AA telah mengalami perkembangan motorik halus secara bertahap, dan tingkat perkembangan anak berada pada tahap mulai berkembang (MB).

Kata Kunci: asesmen dinamis, perkembangan, motorik halus.

\section{Pendahuluan}

Pendidikan anak usia dini merupakan suatu lembaga pendidikan dasar dan pondasi awal untuk mengembangkan dan menstimulus tumbuh kembang anak. Proses perkembangan dan pertumbuhan pada anak tentu perlu dilihat dan diukur sesuai dengan tahapan dan perkembangan setiap anak. Karena anak mengalami proses perkembangan dan pertumbuhan secara holistik atau menyeluruh. Tentu setiap anak mengalami pertumbuhan dan perkembangan yang berbeda-beda antara anak yang satu dengan yang lain.

Proses pembelajaran di lembaga pendidikan anak usia dini memiliki perbedaan yang sangat signifikan dibandingkan dengan jenjang pendidikan yang lainnya. Karena proses pembelajaran di lembaga pendidikan anak usia dini memerlukan model pembelajaran yang kreatif, unik, inovatif, dan menyenangkan. Selain itu, proses penilaian di pendidikan anak usia dini juga berbeda dari jenjang pendidikan lainnya. Pendidikan anak usia dini didirikan dalam mengembangkan seluruh aspek kepribadian anak untuk menjembatani kehidupan dalam keluarga dengan pendidikan di sekolah. Pendidikan anak usia dini, memiliki kekhususan, yaitu belajar sambil bermain, pembelajaran berpusat pada anak, sehingga penilaian yang dilakukan harus memiliki kekhususan tersendiri, yang harus dilaksanakan dengan cermat dan hati-hati. Karena dengan 


\section{JURNAL EDUKASI ANAK USIA DINI \\ PENDIDIKAN ISLAM ANAK USIA DINI \\ UNIVERSITAS ISLAM NEGERI ANTASARI BANJARMASIN}

melakukan penilaian kepada anak maka akan menentukan langkah apa yang harus kita ambil untuk pembelajaran selanjutnya.

Penilaian mencakup berbagai langkah yaitu mengumpulkan data tentang perkembangan dan pembelajaran anak, menentukan pentingnya program dalam mempertimbangkan tujuan program, memasukkan informasi ke dalam perencanaan bagi individu-individu dan program, dan menyampaikan penemuan-penemuan kepada keluarga anak dan pihak-pihak terkait lainnya. Penilaian kemajuan anak terpadu dengan kurikulum dan pengajaran.

Asesmen adalah suatu proses pengumpulan data atau informasi (termasuk pengolahan dan pendokumentasian) secara sistematis tentang suatu atribut, orang atau objek, baik berupa data kualitatif maupun kuantitatif tentang jumlah, keadaan, kemampuan, atau kemajuan suatu atribut, objek atau orang/individu yang dinilai, tanpa merujuk pada keputusan nilai (value judgement) (A. Muri, 2015, p. 14). Asesmen atau yang lebih dikenal dengan penilaian, merupakan kegiatan evaluasi pembelajaran. Penilaian dilakukan untuk memperoleh informasi mengenai pencapaian peserta didik selama kegiatan belajar mengajar.

Asesmen dinamis atau penilaian dinamis adalah bentuk penilaian alternatif yang dapat terikat dengan bentuk penilaian lainnya. Dalam jenis penilaian ini, anak terlibat langsung dalam proses pembelajaran, dengan menggunakan pembelajaran yang dimediasi dengan pengalaman (Gullo, 2005). Penilaian dinamis adalah sejenis penilaian interaktif yang digunakan dalam pendidikan dan profesi pembantu. Penilaian dinamis juga produk dari penelitian yang dilakukan oleh psikolog perkembangan Lev Vygotsky Sebagai modalitas penilaian alternatif, ini berupaya 


\section{JURNAL EDUKASI ANAK USIA DINI \\ PENDIDIKAN ISLAM ANAK USIA DINI \\ UNIVERSITAS ISLAM NEGERI ANTASARI BANJARMASIN}

mengidentifikasi keterampilan yang dimiliki seorang anak serta potensi belajarnya. Prosedur penilaian dinamis menekankan pada proses pembelajaran dan memperhitungkan jumlah dan sifat investasi penguji. Ini sangat interaktif dan berorientasi pada proses. Salah satu tujuan penilaian dinamis adalah untuk menentukan apakah seorang siswa memiliki potensi untuk mempelajari keterampilan baru. Ada dua pendekatan utama untuk DA: Interactionist dan Interventonist (Lidz, 2003).

Dimediasi pengalaman belajar dapat digambarkan sebagai interaksi yang terjadi antara penilai dan seorang anak. Penilai memediasi lingkungan kepada anak melalui pembingkaian yang tepat, memilih, fokus, dan memberi makan. Ingatkan kembali kepada anak pengalaman yang dimiliki si anak. Tujuan berpose dalam melakukan ini adalah menghasilkan sistem pembelajaran yang tepat dan rutinitas untuk anak. Kegiatan kurikulum aktual terdiri dari tugas penilaian yang disajikan kepada anak. Penilaian dinamis adalah prosedur yang dirancang oleh Reuven Feuerstein (1979-1980) dan didasarkan pada teori karya Vygotsky (19781986).

Perkembangan motorik anak terbagi menjadi dua yaitu, perkembangan motorik kasar dan motorik halus. Ada dua prinsip utama yang tampak dalam bentuk keterampilan motorik anak yaitu perkembangan motorik itu berlangsung dari yang sederhana kepada yang kompleks, perkembangan motorik itu berlangsung dari yang kasar dan global kepada yang halus dan spesifik tetapi terkoordinasi (Novan Ardy Wiyani, 2016, p. 37). Kegiatan motorik kasar, merupakan aktivitas anak yang menggunakan otot besarnya. Motorik kasar adalah aktivitas yang berhubungan dengan aktivitas yang menggunakan seluruh 


\section{JURNAL EDUKASI ANAK USIA DINI \\ PENDIDIKAN ISLAM ANAK USIA DINI \\ UNIVERSITAS ISLAM NEGERI ANTASARI BANJARMASIN}

anggota tubuh seperti merangkak, merayap, berjalan, memanjat, melompat, meloncat, melompati dan melempar.

Gerakan motorik atau adalah suatu istilah yang digunakan untuk menggambarkan perilaku gerakan yang dilakukan oleh tubuh manusia. Pengendalian motorik biasanya digunakan dalam bidang ilmu psikologi, fisiologi, neurofisiologi maupun olah raga. Proses tumbuh kembang kemampuan gerak seorang anak. Pada dasarnya, perkembangan Perkembangan motorik adalah ini berkembang sejalan dengn kematangan saraf dan otot anak. Sehingga, setiap gerakan sesederhana apapun, adalah merupakan hasil pola interaksi yang kompleks dari berbagai bagian dan system dalam tubuh yang dikontrol oleh otak.

Berkaitan dengan kemampuan motorik menurut Waharsono (Waspada, 2014, p. 33) mengemukakan bahwa sejalan dengan meningkatnya ukuran tubuh dan meningkatnya kemampuan fisik, maka meningkat pulalah kemampuan geraknya. Pencapaian suatu kemampuan pada setiap anak bisa berbeda-beda, namun demikian ada patokan umur tentang kemampuan apa saja yang perlu dicapai seorang anak pada usia tertentu (Sutini, 2018, p. 74).

Kemampuan motorik anak berbeda-beda, ada yang lambat dan ada pula yang sesuai dengan perkembangan tergantung pada kematangan anak. Oleh karena itu sejak usia dini aspek pengembangan motorik anak dalam bentuk kegiatan yang menyenangkan dapat menstimulus perkembangan motorik anak secara maksimal khususnya perkembangan motorik halus anak. Kegiatan tersebut dilakukan dengan cara bermain, gerakan motorik anak akan berdampak positif pada aspek perkembangan yang lainnya (Sutini \& Rahmawati, 2018, p. 50).

Gerakan motorik halus adalah gerakan yang hanya melibatkan otot-otot kecil, seperti keterampilan menggunakan 


\section{JURNAL EDUKASI ANAK USIA DINI \\ PENDIDIKAN ISLAM ANAK USIA DINI \\ UNIVERSITAS ISLAM NEGERI ANTASARI BANJARMASIN}

jari-jemari tangan dan gerakan pergelangan tangan yang tepat (Sujiono et al., 2014, p. 114). Aktivitas motorik halus merupakan keahlian gerakan yang melibatkan otot-otot kecil yang terdiri dari koordinasi mata dan tangan yang terkoordinasi secara seimbang sehingga menciptakan suatu keterampilan. Dalam cara kerjanya gerakan motorik halus tidak terlalu membutuhkan banyak tenaga melainkan hanya melibatkan koordinasi mata dan gerakan tangan yang cermat. Pada anak yang sudah baik kematangan motorik halusnya biasanya cenderung menunjukkan aktivitas kemandirian karena tangannya sudah dapat terampil untuk melakukan berbagai hal.

Kemampuan motorik halus berkaitan dengan keterampilan menggerakkan otot-otot kecil. Motorik halus berkaitan dengan gerakan-gerakan yang lebih spesifik dibandingkan motorik kasar menyangkut koordinasi gerakan jari-jari tangan dalam melakukan berbagai aktivitas, seperti menyusun, memberi warna, merangkai, dan menggunting kertas dengan satu tangan, sementara yang lain digunakan untuk menggambar atau kegiatan lainnya. Pola pola gerakan ditunjukkan sebagai keterampilan koordinasi mata dan tangan. Keterampilan motorik halus lebih banyak menggunakan jari jemari anak dalam berbagai aktivitasnya. Pengembangan kemamuan motorik halus harus melalui berbagai kegiatan yang menarik dan bervariatif dengan bermain, karena bermain asensi segala aktivitas anak (Hartinah, Mayar, \& Suryana, 2019, p. 55).

Standar tingkat pencapaian perkembangan anak (STTPA) perkembangan motorik halus anak usia 3-4 tahun yaitu, pertama, menuang air, pasir atau biji-bijian ke dalam tempat penampung (mangkuk, ember); kedua, meronce benda yang cukup besar; dan ketiga, menggunting kertas mengikuti pola garis lurus (Permendikbud, 2014). Pengembangan karakteristik 


\section{JURNAL EDUKASI ANAK USIA DINI \\ PENDIDIKAN ISLAM ANAK USIA DINI \\ UNIVERSITAS ISLAM NEGERI ANTASARI BANJARMASIN}

motorik halus anak lebih ditekankan pada gerakan-gerakan tubuh yang lebih spesifik seperti menulis, menggambar, menggunting, dan melipat (Indraswari, 2012, p. 03).

Teknik asesmen dinamis motorik halus anak terdapat empat teknik, diantaranya ialah, pertama teknik portofolio. Portofolio terdiri dari contoh hasil karya anak, hasil penilaian anak berdasarkan instrumen yang telah disusun, foto-foto kegiatan dan beberapa pendukung lainnya seperti hasil penilaian (Suyadi \& Dahlia, 2014, p. 139). Asesmen portofolio menurut Mc.Millan (Ningtyas \& Risina, 2018, p. 02), proses yang dilakukan mampu mengakomodasi penilaian hasil belajar sikap dan keterampilan serta mampu mengukur proses belajar siswa. Siswa atau peserta didik diberi peluang untuk menganalisis dan mengkritik pekerjaan sendiri maupun karya peserta didik yang lainnya. Selain itu juga dalam proses asesmen yang dilakukan proses pembelajaran terdapat tiga ranah yaitu: 1) Ranah pengetahuan; 2) Ranah sikap; 3) Ranah keterampilan. Berdasarkan penjabaran di atas penulis menghubungkan dengan proses pembelajaran di dalam pendidikan anak usia dini, adanya asesmen dari tiga ranah tersebut. Tentu jika diimplementasikan akan menghasilkan suatu data yang menjadi bagian dari asesmen portofolio untuk anak usia dini. Konten isi yang berkaitan dengan asesmen portofolio yakni berkaitan dengan informasi yang termasuk dalam portofolio sebagai dokumentasi perubahan perilaku pada anak-anak harus dikumpulkan dari berbagai sumber, melalui berbagai metode, dan dari berbagai titik waktu. Meskipun ada banyak jenis item yang dapat dipilih untuk dimasukkan dalam portofolio anak, item tersebut harus mencerminkan pekerjaan yang dilakukan anak secara spontan sebagai bagian dari kurikulum. 


\section{JURNAL EDUKASI ANAK USIA DINI \\ PENDIDIKAN ISLAM ANAK USIA DINI \\ UNIVERSITAS ISLAM NEGERI ANTASARI BANJARMASIN}

Kedua, teknik hasil karya. Misalnya gambar, lukisan, melipat, kolase, hasil guntingan, tulisan atau coretan, roncean, dan lain sebagainya (Zahro, 2015, p. 102).

Ketiga, teknik observasi, teknik ini merupakan cara pengumpulan data untuk mendapatkan informasi melalui pengamatan langsung terhadap sikap dan perilaku anak. Untuk kepentingan tersebut, diperlukan pedoman yang mengacu pada indikator yang telah ditetapkan. Observasi dapat dilakukan dengan cara mengamati berbagai perilaku atau perubahan yang terjadi yang ditunjukkan anak selama kurun waktu tertentu. Sehingga observasi dapat terarah dengan cara guru harus menggunakan instrumen observasi dengan mengacu pada indikator pencapaian anak.

Keempat, teknik catatan anekdot. Catatan anekdot memiliki beberapa macam bentuk yaitu bentuk evaluatif, bentuk pertanyaan yang menerangkan penilaian guru berdasarkan ukuran baik-buruk, yang diinginkan dan tidak-diinginkan, yang diterima dan tidak diterima, bentuk interpretatif, berupa penafsiran terhadap perilaku yang telah diamati oleh guru yang didukung oleh faktor yang diamatinya, bentuk deskripsi umum, berupa catatan dan pernyataan umum tentang perilaku anak didik dalam situasi tertentu, bentuk deskripsi khusus, berupa catatan dan pernyataan khusus tentang perilaku anak didik dalam situasi tertentu (Mulyasa, 2017, p. 200). Catatan anekdot adalah catatan sikap dan perilaku siswa dalam situasi khusus. Situasi khusus di seini adalah kejadian yang muncul di luar kebiasaan siswa, baik kejadian yang sifatnya menunjang perkembangannya maupun yang perlu mendapat perhatian khusus (Suyadi \& Dahlia, 2014).

Pembahasan dan penjelasan dalam penelitian ini berfokus pada aspek perkembangan motorik halus anak usia 3-4 tahun di 


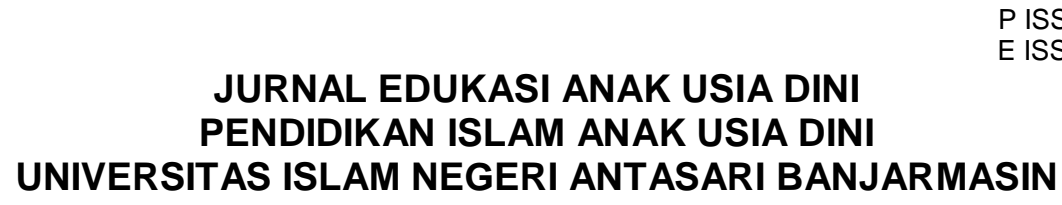

KB (Kelompok Bermain) Mutiara Ummi, Kalasan. Pada tahapan ini, anak mampu mengembangkan perkembangan motorik halusnya seperti hal perkembangan biasa yakni memasukkan biji ke dalam botol, meremas kertas, memegang sendok atau pensil, dan lain sebagainya. Hasil pengamatan dalam pra-penelitian di Kelompok Bermain (KB) Mutiara Ummi, Kalasan terdapat anak yang berinisial AA belum berkembang dengan maksimal pada tahapan perkembangan motorik halusnya. Guru atau pendidik tentu menerapkan asesmen berbasis dinamis untuk mengetahui hasil tahapan pencapaian perkembangan anak. Proses tahapan asesmen dinamis perkembangan motorik halus anak yang berinsial AA akan dibahas lebih rinci dan jelas pada artikel ini.

Penelitian ini tentunya memiliki tujuan tersendiri, yaitu mendeskripsikan penilaian dinamis terhadap seorang anak yang berinisial AA tentang perkembangan motorik halusnya. Berdasarkan pra interview dengan guru kelas, mampu mengikuti kegiatan yang menstimulus perkembangan motorik halusnya secara bertahap.

\section{Metode Penelitian}

Penelitian ini menggunakan metode penelitian deskriptif kualitatif berbasis studi kasus. Teknik penelitian ini menggunakan wawancara, dan studi dokumentasi. Pada teknik wawancara, peneliti menggunakan pedoman wawancara terstruktur kepada guru yang bersangkutan, observasi menggunakan checklist, sedangkan pada dokumentasi, peneliti menggunakan hasil karya anak. Data-data yang sudah dikumpulkan selanjutnya dianalisis dengan model interaktif melalui tahapan reduksi, penyajian dan penyimpulan data model Miles \& Huberman. 


\section{JURNAL EDUKASI ANAK USIA DINI \\ PENDIDIKAN ISLAM ANAK USIA DINI \\ UNIVERSITAS ISLAM NEGERI ANTASARI BANJARMASIN}

\section{Hasil dan Pembahasan}

Anak yang berinisial $A A$ merupakan anak yang tipe belajarnya berbeda dengan anak yang lainnya. Ketika teman sebayanya sudah mampu mencapai perkembangannya sesuai usianya, AA belum mampu untuk mencapai perkembangannya. Penelitian ini berfokus bagaimana AA berproses untuk mencapai perkembangan dan bagaimana guru mengimplementasikan strategi asesmen dinamis terhadap AA. Berdasarkan hasil wawancara dan studi dokumentasi dengan guru yang berkaitan, untuk mengimplementasikan strategi asesmen dinamis ini, guru menggunakan bentuk penilaian observasi dalam bentuk checklist, hasil kerja anak dan portofolio.

\section{Analisis Hasil Checklist Harian Perkembangan Motorik}

\section{Halus Anak}

\begin{tabular}{|c|c|c|c|c|c|}
\hline No & Perkembangan Motorik Halus Anak Usia 3-4 & BB & MB & $\mathrm{BSH}$ & BSB \\
\hline 1 & $\begin{array}{l}\text { Menuang air, pasir, atau biji-bijian ke dalam } \\
\text { tempat penampung (mangkuk, ember) }\end{array}$ & & $\sqrt{ }$ & & \\
\hline 2 & $\begin{array}{l}\text { Memasukkan benda kecil ke dalam botol } \\
\text { (potongan lidi, kerikil, biji-bijian) }\end{array}$ & & $\sqrt{ }$ & & \\
\hline 3 & Meronce benda yang cukup besar & & $\sqrt{ }$ & & \\
\hline 4 & $\begin{array}{l}\text { Menggunting kertas mengikuti pola garis } \\
\text { lurus }\end{array}$ & & $\sqrt{ }$ & & \\
\hline
\end{tabular}

\section{Keterangan:}

$\mathrm{BB}=$ Belum Berkembang

$\mathrm{MB}=$ Masih Berkembang

BSH = Berkembang Sesuai Harapan

BSB = Berkembang Sangat Baik

Berdasarkan tabel di atas, pada indikator perkembangan motorik anak berdasarkan penilaian hasil checklist harian bahwa indikator menuang air, pasir, atau biji-bijian ke dalam tempat 


\section{JURNAL EDUKASI ANAK USIA DINI \\ PENDIDIKAN ISLAM ANAK USIA DINI \\ UNIVERSITAS ISLAM NEGERI ANTASARI BANJARMASIN}

penampung (mangkuk, ember), memasukkan benda kecil ke dalam botol, meronce benda yang cukup besar dan menggunting kertas mengikuti pola garis lurus bahwa tingkat pencapaian perkembangan motorik halus anak usia 3-4 tahun berada pada tahap mulai berkembang. Hal ini dikarenakan ketika melakukan aktivitas dalam proses pembelajaran, anak AA masih kesulitan untuk melakukan sendiri tanpa bantuan dari guru, sehingga untuk melakukan aktivitas membutuhkan bantuan arahan dari guru di sentra.

\section{Analisis Hasil Portofolio Perkembangan Motorik Halus Anak}

\begin{tabular}{|c|c|c|c|c|c|}
\hline No & Hasil Karya & BB & MB & $\mathrm{BSH}$ & BSB \\
\hline 1 & $\begin{array}{l}\text { Hasil Karya Mencap menggunakan pelepah } \\
\text { pisang }\end{array}$ & & $\sqrt{ }$ & & \\
\hline 2 & Mengkolase menggunakan daun kering & & $\sqrt{ }$ & & \\
\hline 3 & Membuat Bakso dari Plastisin & & $\sqrt{ }$ & & \\
\hline
\end{tabular}

$\mathrm{BB}=$ Belum Berkembang

$\mathrm{MB}=$ Masih Berkembang

$\mathrm{BSH}=$ Berkembang Sesuai Harapan

$\mathrm{BSB}=$ Berkembang Sangat Baik

Berdasarkan tabel diatas, bahwa pada indikator mencap menggunakan pelapah pisang, mengkolase menggunakan daun kering, dan membuat bakso dengan plastisin untuk anak AA masih berada pada tahap mulai berkembang, hal ini dikarenakan ketika melakukan kegiatan tersebut, anak masih membutuhkan bantuan dari guru untuk diarahkan dalam menyelesaikan aktivitas yang diberikan oleh guru. 


\section{JURNAL EDUKASI ANAK USIA DINI \\ PENDIDIKAN ISLAM ANAK USIA DINI \\ UNIVERSITAS ISLAM NEGERI ANTASARI BANJARMASIN}

\section{Kesimpulan}

Berdasarkan pemaparan diatas, maka dapat disimpulkan bahwa bentuk penelitian yang digunakan oleh guru yang bersangkutan untuk anak yang berinisial AA ialah bentuk observasi checklist dan lembar kerja portofolio. Anak yang berinisial AA telah mengalami perkembangan motorik halus secara bertahap, dan tingkat perkembangan anak berada pada tahap mulai berkembang (MB).

\section{Daftar Pustaka}

A. Muri, Y. (2015). Asesmen dan Evaluasi Pendidikan: Pilar Penyedia Informasi dan Kegiatan Pengendalian Mutu Pendidikan. Jakarta: Kencana.

Gullo, D. F. (2005). Understanding Assessment and Evaluation in

Early Childhood Education. Teachers College Press.

Hartinah, U., Mayar, F., \& Suryana, D. (2019). Efektivitas Mencetak Percikan Daun Terhadap Perkembangan Motorik Halus Anak Di Taman Kanak-Kanak Aisyiyah Suayan. Jurnal Usia Dini, 4(2), 55-66. Retrieved from https://jurnal.unimed.ac.id/2012/index.php/jud/article/view/ 12093

Indraswari, L. (2012). Peningkatan Perkembangan Motorik Halus

Anak Usia Dini Melalaui Kegiatan Mozaik Di Taman KanakKanak Pembina Agam. Jurnal IImiah Pesona PAUD.

Lidz, C. S. (2003). Early Childhood Assessment. Canada: John Wiley \& Sons Inc.

Mulyasa, E. (2017). Manajemen PAUD. Bandung: PT Remaja Rosdakarya.

Ningtyas, D. P., \& Risina, D. F. (2018). Peningkatan Self 


\section{JURNAL EDUKASI ANAK USIA DINI \\ PENDIDIKAN ISLAM ANAK USIA DINI \\ UNIVERSITAS ISLAM NEGERI ANTASARI BANJARMASIN}

Awareness Anak Usia Dini Melalui Media Video Mitigasi Bencana Gunung Meletus. AL-ATHFAL: JURNAL PENDIDIKAN ANAK, 4(2), 113-124. https://doi.org/10.14421/alathfal.2018.42-01

Novan Ardy Wiyani. (2016). Konsep Dasar PAUD. Yogyakarta: Gava Media.

Sujiono, B., Sumantri, M., Aisyah, S., Tatminingsih, S., Amini, M., \& Suroso, A. (2014). Metode Pengembangan Fisik. Jakarta: Universitas Terbuka.

Sutini, A. (2018). Meningkatkan Keterampilan Motorik Anak Usia Dini Melalui Permainan Tradisional. Cakrawala Dini: Jurnal Pendidikan Anak Usia Dini, 4(2). Retrieved from http://ejournal.upi.edu/index.php/cakrawaladini/article/view/ $10386 / 6431$

Sutini, A., \& Rahmawati, M. (2018). Mengembangkan Kemampuan Motorik Halus Anak Melalui Model Pembelajaran BALS. Cakrawala Dini: Jurnal Pendidikan Anak Usia Dini, $6(2)$.

Suyadi, \& Dahlia. (2014). Implementasi dan Inovasi Kurikulum

PAUD 2013. Yogyakarta: Remaja Rosdakarya.

Waspada, E. (2014). Perbedaan Pengaruh Permainan Tradisional dan Latihan Kecerdasan Kinestetik terhadap Kemampuan Motorik dan Kecerdasan Emosional. Universitas Sebelas Maret.

Zahro, I. F. (2015). Penilaian dalam Pembelajaran Anak Usia Dini. Tunas Siliwangi. 